\title{
日露戦争を契機とする牛価高騰と食肉供給の多様化
}

\author{
野間万里子（京都大学大学院農学研究科）
}

\section{Sudden Rise in Cattle Price and Diversification of Meat Supply, after the Russo-Japanese War}

\author{
Noma Mariko (Graduate School of Agriculture, Kyoto University)
}

The purpose of this paper is to clarify the change in meat supply after the Russo-Japanese War. The war resulted in the shortage of cattle and increase in its price. The shortage suggests that the limitation of meat supply depended on the existence of cattle not only for meat but also (and mainly) for farming. The solution was found in importing meat from Australia and cattle from the Korean peninsula and supplementing the lack of beef with pork.

\section{1.はじめに}

筆者はこれまで近代日本に抢ける肉食受容につい て研究を行らなかで, (1)牛鍋といら消費形態で受容 されたこと，(2)文明開化期の牛鍋ブームが広範に存 在した役牛を利用することで可能になったこと ${ }^{1)}$, (3)明治後期には役肉兼用といら制約を受けながらも 肥育技術が展開し脂肪交雑の入った高品質な牛肉生 産が目指されるようになったこと ${ }^{22}$ ，を明らかにし てきた

本稿では, 文明開化期以降 2 度目の肉食拡大・普 及の画期とされる日露戦争が食肉生産・供給に与兄 た影響を明らかにすることを目的とする. 日本近代 に打ける肉食に日露戦争が与えたインパクトとして はこれまで, 従軍経験 = 肉食経験として地方への 肉食拡大の消費側の要因として言及されてきた.

供給サイドへの影響としては，これまでにも国内 畜牛業への打撃と, それへの対応としての朝鮮牛輸 入が指摘されている.たとえば大江は「戦時軍需に よる大量屠殺が役牛飼育にいかに深刻な影響をあた 光，乙か子飼育頭数の戦前水準を回復するに 5 年間 を要するとともに, 戦時屠殺による飼育頭数の絶対 数の減少分の実に $44.5 \%$ を輸入に依存しなければ
The import of meat from Australia failed because of the immaturity of refrigerating and freezing tecniques. The import of cattle from the Korean peninsula involved the problem of rinderpest, but it did have two advantages. The first was the high evaluation that these cattle received as farming cattle. The second was that the quality of meat improved during the period they were kept as farming cattle.

ならなかった」3)としている.

輸入にかんしては, 日露戦後の朝鮮牛輸入の本格 化と, 第一次世界大戦内でのドイッとの戦争（日独 戦争) に上る膠州湾租借地獲得後の山東牛移入開始 についての制度的, 数量的研究がなされている ${ }^{4}$.

本研究では視点を内地置き, 対象時期は, 食の 変化は時間差を伴って現れるものであるため, 日露 戦時から昭和戦前期までとする.

\section{2. 日露戦役を契機とする牛価高騰}

1904 年 2 月の日露開戦により,「御承知の通軍隊 の糧食中最も緊要で最も力と頼む副食物は何である かと云ふに，牛肉に越すものはありません」5) と， 兵食用の牛肉需要が急増した。これは新しく興って きた栄養学の知識と「牛肉 $=$ 滋養」といら牛鍋ブー ム期以来のイメージとの相混ざったようなものが根 底にあったと思わ机る。

兵食に打ける肉食の中心は生肉(現地調達)であっ たが，缶詰は内地での調達が主となった ${ }^{6)}$. そのた め, 国内での屠牛頭数は，日露開戦前 5 年（18991903）の平均年間屠牛頭数約 20 万頭から 1904 年に は 28 万頭超と約 $40 \%$ もの伸びをみた。 
当時の牛は使役に供されたのち肉用にまわるた め, 肉用屠牛数の増大はそのまま使役牛の減少とい らことになる，そのため，「頃日は出征軍隊に供給 する缶詰用のため多大の屠牛を要します。 (中略) 縦 令有る限りの牛を用ふれば軍隊の供給は事足るとす るも，斯くては耕運上に事を欠き，由々しき大事を 惹き起すことは火をみるよりも明かであります.」7) といらょうに，農業への支障が懸念されるまでに なった。

実際，「因州や作州辺では日露交戦開始以来食用 牛の売買益々頻繁で, 之が為め価格は頓に昂騰し, 従来牝牛一頭六十円位のものは九十円乃至百円に上 りましたが, 農家は為めに非常の困難を来たし, 中 等以下の農家にては到底自ら飼牛して農耕を為す能 はず」8)と, 生牛価格が開戦前の 1.5 倍ほどに跳ね 上がった地方もあった。

生肉価格では, 1904 年には牛肉 100 斤 18-19 円 といら相場だったのが 1905 年 3 月には 100 斤 25 円 前後になっている ${ }^{9)}$. これを伝える記事では，「価 格昂騰の主因は第一軍需品にあり」としているが, 直接の軍需増加だけではなく，それを見込んだ商人 による投機的買占め, 馬使役地帯での馬匹徽発の影 響を受けての使役牛需要増加, ロシア人捕虜の収容 なども理由として考兄らていた ${ }^{10)}$. とくに，ロシ ア人捕虜をめぐっては, 日本の「文明度」を示すた めにも, 食事を含めその扱いは重要であった。

この価格高騰は，「昨今二十五円前後（牛肉 100 斤につき……筆者）を唱へて尚ほ騰貴の傾あるより 小売の如きは非常の欠乏を告げて中には閉店するも のさへあるに至り為めに濠洲肉の輸入説さへ唱へら るるに至れり」 ${ }^{11}$ といらょうに, 外国からの輸入を 仰ぎ国内の牛生産の不足分を補らことが想定される までの事態となっていた。

牛肉需要の増加は, 戦役による一時的なものとし て捉えられていたわけではない.「戦捷後は所謂事業 の膨張やら, 経済界の発展やらで, 世間の需要は頓 に増加を見ることは，過去廿七八年後日清戦役後の 実例に徵して明かに推測し得られます」12) と, 戦後 も引き続き肉食需要が増加すると見込まれていた。

輸入に対しては,「(牛肉の価格高騰を抑えるには) 濠洲産の凍肉を輸入するが尤も妙策なり」 ${ }^{13)}$ と期待 感を表明する論者もいたが，一方では「此期に乗じ て涼洲や亜米利加から盛に牛が輸入されるのは必定
です，洵に恐るべく且つ宜しく今に方て警戒を加ふ ベきことと深く心配いたします.」14) と，廉価な外 国牛が輸入されれば国内畜牛業を圧迫するのではな いかとの警戒感も併存していた。

\section{3. 食肉供給の多様化 \\ (1) 濠洲牛肉輸入の試み}

牛価高騰を緩和するものとして，濠洲肉輸入，朝 鮮牛輸入本格化が浮上した。濛州牛肉輸入が挙げら れたのは，安価でかつ良質であると考えられていた ためである. 1907 年，一旦落ち着いた国内牛肉価 格と比較しても「米國及び涼洲の冷蔵肉を輸入せん とし既に電報にて多量の注文を発したるものありし が右は関税一切の懸りを加ふるも十分現時の肉相場 と競争し得べしと云ふ」 ${ }^{15)}$ と，輸送費や関税を考慮 しても国内牛肉相場と競争できると見積もられてい た。しかし，1908 年 10 月 29 日日本冷蔵株式会社 の第一便で牛肉 10 万 8 千斤，羊肉 1 万 1200 斤が到 着したが，その価格は 1 斤 27-8 銭と ${ }^{16)}$ ，高騰した 国内牛肉価格をやや上回る水準であった。

農商務省の調査によると，1904-1907 年の濠洲に おける牛肉百多平均価格は 6 銭 2 厘余りであり, 輸 入しても百多 17-18 銭だったといらことだが，供給 も需用も少なく「遂に必敗に帰せり」と言われた ${ }^{17}$.

失敗の理由としては, 以下 6 点が指摘されている. (1)小売業者の体力

「本邦に於ける屠肉問屋と小売営業者との利益の 差は非常に懸隔し居るを以て偶々海外より低廉なる 肉を輸入して市場に供給するも小売業者は為めに何 等の痛痒を受くることなく十分に競争の余力ありし に依る」

(2)解凍技術の問題

「冷蔵したる肉は一旦空気に曝露するときは急激 なる変化を来し甚しく味を損するは事実なり，(中 略）而して此常態に復するには適当に温度の加減を 調節すること極めて必要にして若し此温度の加減を 䛊るときは其の味に影響すること少からず」

(3)冷蔵事業の未発達

「当時冷蔵事業は未た幼稚にして冷肉を常態に復 する所の技術も完からさる結果其の味を損したるは 事実なり」

(4)調理法・嗜好の違い

「生肉使用の状態は彼我全く其の趣を異にせり彼 
地に於ては多く冷蔵したる肉を用ふるも本邦は然ら 寸，元来冷蔵肉は鍋焼に適せさるを以て未た本邦人 の嗜好に投すること能はさるなり」

(5)肉質の違い

「濠洲生牛肉は水分多く且味淡くして全く本邦産 牛肉に匹敵すること能はさるは事実なり」

(6)輸入肉に対する忌避感

「本邦人は甚しく輸入せる生肉を忌む傾向あり或 は害毒あるにあらさるやの危惧を抱く者多し」

とくに，(4)調理法・嗜好の違いについては，牛肉 食 $=$ 牛鍋・すきやきとして受容された，消費形態 と深く関係していることが分る。また，(2)・(3)から は, 冷蔵・冷凍といら発展途上にある新しい技術の 制約が見えてこょう.

こらした理由もあって濠洲肉輸入は, 日露戦役か らしばらくすると下火になってしまう。それでも， 昭和期にも濠洲肉輸入は行われており，1926-1932 年, 東京市で消費される輸入肉の 80-97\%といら大 部分は青島肉であったものの, 残り 3-20\%は「濠 洲其他（伯刺西爾，支那，濠太刺利，加奈陀，北米 合衆国, 覀爾然丁, 墺太利)」18) からの輸入であった. 重量にすると多い年で 60 万 $\mathrm{kg}$ 足らず，少ない年で 7-8 万 $\mathrm{kg}$ といら少量ではあるものの, 冷蔵・冷凍 技術を利用した輸入は続く. その端緒が日露戦争に あったのだ.

\section{（2）朝鮮牛輸移入}

日露戦時の牛価高騰は, 中国と並んで「牛疫の常 在地」 ${ }^{19)}$ と目されていた朝鮮半島からの生牛輸入を 本格化させた. 図 1 は朝鮮半島からの生牛輸移入頭 数を示したものである. 併合後はロシア向の輸出が 減少し，注とんどが内地向に移出されるようになっ ている. 朝鮮牛輸入は日露戦前から行わ机ていたが, 韓国で頻繁に発生していた牛疫を持ち込むといら問 題があり，1892-1904 年には毎年のように牛疫の侵

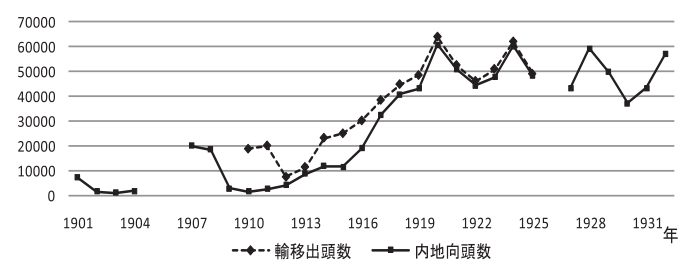

図 1. 朝鮮牛輸移入頭数（1901-1932）

朝鮮総督府殖産局『朝鮮の畜産』1927 年, 朝鮮獣医畜産 学会『昭和七年朝鮮畜産統計』1933 年より作成
入に悩まされていた ${ }^{20)}$.

まずは中里 ${ }^{21)}$ によりながら簡単に牛疫対策をま とめて括こう。1905 年に福岡県輸入獣類検疫所を 設置するが，それでも1908 年には牛疫の大流行を み, 1909 年, 輸出牛検疫法が制定される. 1909 年 の輸出牛検疫法は, 釜山に設置された検疫所で 9 日 間繋留した後, 内地検疫所でも 9 日間繋留すること を定めたものである。日露戦争後に韓国が日本の保 護国化したことでこの二重検疫制が可能となり，そ の後の朝鮮牛移入増加を促進したのである.

二重検疫制は韓国併合後の 1915 年朝鮮移出牛検 疫規則により廃止される，釜山にて 18-20日検疫を 受けた後, 内地では視診のみへと変更になり,さら に 1920 年の改正では釜山での検疫期間が 12-20 日 へと短縮され，さらに簡易なものとなった。 こうし た検疫制度の整備は朝鮮牛移入の円滑化を進めるも のであった.

これらの制度整備によって，朝鮮牛が続々と内地 へ送られるようになったが，『畜産彙纂』第 9 号 22 ではそらした状沉を承けて1925 年の内地に打ける 朝鮮牛の状沉についてまとめている.これによると, 総屠牛頭数約 32 万頭のらち, 7 万頭超が朝鮮牛で あり，実に $22.4 \%$ 朝鮮牛が占めている。もはや朝 鮮牛なしでは到底内地の食肉需要を満たすことが不 可能であったといえる。

道府県別にみると，頭数では兵庫県（21 997 頭)， 大阪府（15 482 頭），東京府（8930 頭）が上位に並 んでいるが，比率では兵庫県 $(75.9 \%)$ ，高知県 $(70.0 \%)$ ，奈良県 $(48.3 \%)$ と西日本で高くなって いる.

朝鮮牛移入がこれほぞ拡大した理由の一つは，そ の役牛としての高い評価である。「一，性質極めて 静温順良にして制御し易きこと二，性能怜悧にし て能く命令を守り仕事に堪能なること三，体格偉 大，体質強健にして罹病少なきこと（中略）五， 粗食に堪へ飼養管理の手数を省くこと（後略）」 ${ }^{23}$ というのは典型的な役牛としての朝鮮牛評である.

ただ，その肉質にかんしては，輸入本格化当時は， 「その肉は外観程にあらず概して我が最上等には及 ばざるも缶詰などには最も適当なりと云ふ」 ${ }^{24)}$ ，「其 過度に使役する結果と繁殖力の劇しい結果とは著し く肉用としての価值を減じて，大牢の滋味などと云 ふ事は到底朝鮮牛には望めない」 ${ }^{25)}$ と, 一般には評 
価が低かった． $2 つ$ 目の引用からは朝鮮牛の役牛ま たは繁殖牛としての長所が肉牛としてはマイナスに 出ているといらことが分る。

しかし時期を下り 1920 年代になると，「肉用とし ての価值は成熟期の晚き不利あるも味や美にして兼 用するに足り」 ${ }^{26)}$, 「朝鮮牛の肉は概して脂肪に乏 しいから内地牛に比しては肉味が稍不良であるとも 云はれて居るが，移入後内地で飼養せられたものは 内地牛と大差はない，しかし肥光いされたものは脂 肪が多くなつて軟らかく肉味も頗る佳良となるので ある」 27) とする声も聞かれた.

昭和初めごろの各道府県での肉牛としての朝鮮牛 評価が分かる ${ }^{28)}$ ，そ机によると，47 道府県中 16 府 県に扮いて内地牛よりも劣るとされているが，26 府県では内地牛と同等とされている ${ }^{29}$. 同等とする 府県で注目すべきは, 移入後内地で半年から 2 年使 用することで内地牛との差がなくなるとしている県 がみら机ることである ${ }^{30}$. こ机は，役肉兼用といら 牛飼養条件の中での生牛移入の利点といえる.

内地牛よりも劣るとする理由中目立つのは脂肪が 少ないことである。すでに内地では，脂肪交雑を目 標と寸る肥育が展開し，その肥育地によって「本場 物」「場違物」31) とされるほどであった。本場とさ れる肥育地は滋賀県近江八幡, 三重県伊勢松坂, 山 口県徳山や兵庫県など西日本に集中していたが，朝 鮮牛評価の低い府県もほ济西日本であり ${ }^{32}$, 肥育度 の高いところで，肉牛としての朝鮮牛評価が低かっ たと言えるかもしれない。

\section{（3）豚肉生産の拡大}

図 2 は 1899-1911 年の牛豚屠畜頭数である. 日露 戦後に屠豚頭数の増加が始まっていることが分か る. さらに 1918 年以降は屠豚頭数が屠牛頭数を上 回るよらになり，1939 年には 126 万頭を超兄戦前 のピークを記録する，枝肉量でみても，牛豚合計の 伸びのほとんどが豚枝肉の伸びに由る状態となる. 第一次世界大戦では, 日本は自ら日独戦争を戦らの に加えて交戦諸国に牛缶を輸出したため, 再び戦争 によって牛価が高騰している.

次に掲げたのは，日露開戦前の 1903 年，新聞に 連載され好評を博した食をテーマとした啓蒙小説の 一場面である。

「僕は今まで折々豚を食べたけれを゙もあんまり美 味いと思ったことがない。豚は不味いものと心得て

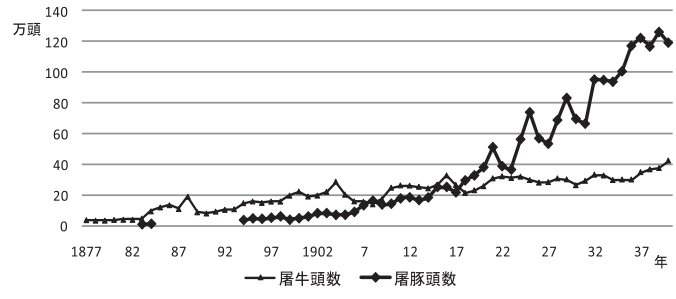

図 2. 屠牛豚頭数（1877-1940）

いたが料理法次第でそんなに美味くなるかね」「美 味くなるとも，牛肉の上等よりもな扮美味い」「マ サカ」「イイエ実際だよ」（中略）「僕は日本人の肉 食を盛にするため豚の利用法を天下に広めたいと思 ら。豚の肉は牛肉よりも価が廉くって巧調理する と牛肉より美味くなる.豚の肉は全く調理法次第だ. （中略）君が依然食べたというのはどらいう風に料 理したか」「牛肉の煮込のように鍋の中へ豚の生肉 を打ち込んで煮たのさ」33)

文明開化期の牛鍋ブーム以降肉を食する際の調理 法の中心であった鍋と豚肉との相性の悪さが，豚肉 食がなかなか広まらなかった一因と解されている。

大正期以降，一方では滋賀県など肥育地では脂肪 交雑の入った鍋料理向きの高級牛肉が生産されるよ らになった。他方では，都市に沶いて，それまでの 高価で日常とは異なる食事マナーを要請される西洋 料理とは違った簡便な洋食が登場する時期でもあ る。 また家庭内での肉調理も増加し, 肉消費の形態 が多様化した，そうした消費の変化と手を携えての 豚肉生産拡大であったと考兄られる。1908年には 日本で最初の豚肉料理書が出版されている ${ }^{34)}$.

とはいえ, 豚肉の生産・消費とも地域差を伴うも のであった，農林省畜産局『全国都市に於ける主要 畜産物の需要供給概況』1933 年によると, 都市に お汀る豚肉消費量の平均は 366 斥 / 人・年となって いる。 これを地方別にみると関東が 773 斥 / 人・年 と飛びぬけている一方で近畿と四国は 100 多/人・ 年にも満たない35)。生産についても全国の 6 割超を 関東が占めて打り, 関東の豚肉圈としての特性が はっきりと表れている。

\section{4. おわりに}

ここまでみてきたよらに，日露戦時の牛価高騰は それまでの国内に存在した役牛を利用するといら食 肉供給の限界を示したものといえる。軍需増加は牛 
価高騰につながり，役牛の確保にも影響が現れた． さらにこの牛価高騰は戦争といら非常時に打梳る一 時的な牛肉供給不足によるものではおさまらず，濠 洲肉輸入開始や朝鮮牛輸移入本格化, さらには豚肉 生産の伸長といった食肉供給の多様化が戦後も定着 していくこととなった.

濠洲肉輸入は, 冷凍・冷蔵といら新しい技術を 利用するため, 技術上の問題もあり新たな食肉供 給源としてメインとはなりえなかった. さらに消 費側からの要因としては, 文明開化期の牛鍋ブー ム以降食肉消費形態の中心であった鍋料理といら 調理形態との不適合が挙げられる. 豚肉消費の本 格化が牛肉と比べて遅れた一因も, 鍋料理との相 性の悪さであった.

新たな食肉供給源として重要な位置を占めたの が, 朝鮮牛輸移入であった. その要因として, 朝鮮 牛は役牛として高い評価を得ていたことがある. 役 肉兼用時代にこれは大きな意味を持つ. さらに肉質 についても, 内地牛より劣るとされてはいたが, 使 役利用をしながら内地牛と同じ飼養管理を行らこと で一定程度改善が可能であった. 朝鮮牛輸移入が本 格化する時期は, 西日本に多く分布した先進肥育地 で, 脂肪交雑の入った高品質な牛肉生産が普及する 時期でもあった。朝鮮牛の肉質評価が低い府県が西 日本に多くみられたのは，そのためであろう。

帝国圈の拡大といら政治状況に加光，生牛のまま 輸移入することで役牛として使役した後最終的に肉 用にするといら牛飼養状況をうまく活かすことがで きたため, 牛疫といら問題を抱えつつも朝鮮牛輸移 入が推進されることとなった.

本稿では省かざるをえなかったが，日独戦争に よって膠州湾租借地を獲得後, 山東牛・青島肉の移 輸入も本格化する。当初は肉中心であったが, 徐々 に生牛が増えていく，やはり，帝国圈の拡大といら 政治的状況と, 生牛移入の強みによるものであろう.

「殊に我国の肉食法なるものは頗る無鉄砲なやり 方で鋤焼にする一方であるから, 洋牛や雑種肉の如 き不味いものではいくら頭数が殖えた所で結局持て 余すのみである.」36) とされるように，肉質と調理 方法には密接な関連がある. 供給元の多様化 $=$ 肉 質の多様化は消費形態にも影響せずにはいない，明 治後期の牛鍋屋の高級化, 安い洋食屋・中華料理の 登場，家庭内での肉食普及といった消費の多様化と
あわせて考えていくことを今後の課題としたい.

注 1）拙稿「近代日本に打汸肉食受容過程の分析一辻 売，牛鍋と西洋料理一」『農業史研究』日本農業史 学会 40 号 2006 年

2) 拙稿「「滋賀県にお竹子牛肥育の形成過程一戦前期, 役肉兼用時代の肥育論理一」『農林業問題研究』地 域農林経済学会 178 号 2010 年

3）大江志乃夫『日露戦争の軍事史的研究』1976 年 岩波書店 490 頁

4）中里亜夫「明治・大正期飞和预る朝鮮牛輸入 (移入) 取引の展開」『歴史地理学紀要』32 号 1990 年, 新 納豊「植民地期朝鮮にお打る『畜牛改良増殖政策』 の数量的検討」『東洋研究』 135 号 2000 年, 河端 正規「青島守備軍支配化の食牛開発」『立命館大学 人文科学研究所紀要』 82 号 2003 年 12 月, 同「山 東牛貿易の研究一青島守備軍の輸出政策とその権 益一」『社会システム研究』16 号 2008 年 3 月.

5）京都府技師獣医学士古川元直「畜牛家の覚悟」（京 都府臨時郡農会会長会に於る古川技師講話）『日本 畜牛雑誌』大日本畜牛改良同盟会 第 3 号 1905 年

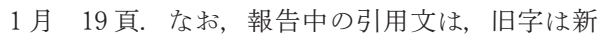
字に, カタカナ混じり文はひらがな交じり文に, 直した、下線，（中略）は報告者による.

6）前揭『日露戦争の軍事史的研究』 486 頁

7）前掲「畜牛家の覚悟」19 頁

8）同上

9）「牛の騰貴と需給」『日本畜牛雑誌』第 7 号 1905 年 6 月 35 頁

10）「食牛漸次減退の兆」『日本畜牛雑誌』第 7 号 1905 年 5 月 38 頁,「労力の補充」『日本畜牛雑誌』第 9 号 1905 年 7 月 12 頁. 日本に収容されたロシア 人捕虜は 7 万人を超えた。（吹浦忠正『捕虜たちの 日露戦争』日本放送出版協会 2005 年 164 頁)

11）前揭「牛の騰貴と需給」35 頁

12）前掲「畜牛家の覚悟」 19 頁

13）「牛肉の直を下る伝」『日本畜牛雑誌』大日本畜牛 改良同盟会 第 6 号 1905 年 5 月 34 頁

14）前揭「畜牛家の覚悟」19 頁

15）「時事 米濠冷蔵肉の輸入」『日本畜牛雑誌』36 号 1907 年 10 月 48 頁

16）「東西南北 生肉十万斤の輸入」『日本畜牛雑誌』 50 号 1908 年 12 月 50 頁

17）農商務省農務局『本邦都市に於ける牛肉の需要と 供給』1912 年 131 頁

18）東京市産業部市場課『屠肉飞関する調査』1933 年 
47-48 頁

19）山脇圭吉『日本家畜防疫史』1939 年 49 頁

20）同上 44-45 頁

21）前掲「明治・大正期に打ける朝鮮牛輸入（移入） 取引の展開」

22）「本邦内地二於ヶル朝鮮牛」『畜産彙䈯第 9 号』農 林省畜産局 1927 年

23）肥塚正太『朝鮮之産牛』1911 年 26 頁

24）「韓国の牧畜業」『日本畜牛雑誌』10 号 1905 年 8 月 34 頁

25）「韓国畜牛業に関する時重博士の断片」『日本畜牛 雑誌』 11 号 1905 年 9 月 7 頁

26）朝鮮総督府殖産局『朝鮮の畜産』1923 年 1 頁, 朝鮮総督府殖産局『朝鮮の畜産』1927 年 1 頁

27）吉田雄次郎『朝鮮の移出牛』1927年 47 頁

28）同上 47-50 頁

29）「該当事項なし」が 5 道県.
30）群馬・埼玉・千葉・東京・石川・香川の 6 府県.

31）羽部義孝『和牛の改良と登録』1940 年 45 頁

32）神奈川, 新潟, 福井, 山梨, 岐阜, 静岡, 滋賀, 京都，奈良，鳥取，岡山，愛媛，高知，福岡，長崎, 熊本の 16 府県.

33）村井弦斎『食道楽（上）』岩波書店 2005 年 37-38 頁（初出は 1903 年 1 月から 1 年間の『報知新聞』 での連載.

34）原田嘉次郎『家庭重宝最新豚料理』が最初とされ ている. 江原絢子・東四柳祥子『近代料理書の世界』 ドメス出版 2008 年 154 頁.

35）農林省畜産局『全国都市に於ける主要畜産物の需 要供給概況』1933 年 10 頁

36）木村条丸（中央常設家畜市場社長）「予は和牛蕃殖 を希望せり」『日本畜牛雑誌』93 号 1912 年 7 月 12 頁 